\title{
The Prevalence of Salmonella spp. in Two Arctic Fox (Alopex lagopus) Farms in Poland
}

\author{
Jan Siemionek ${ }^{\dagger}$, Konrad Przywara and Anna Szczerba-Turek *,+(i) \\ Department of Epizootiology, Faculty of Veterinary Medicine, University of Warmia and Mazury in Olsztyn, \\ Oczapowskiego 13, 10-718 Olsztyn, Poland; jan.siemionek@uwm.edu.pl (J.S.); k.przywara@o2.pl (K.P.) \\ * Correspondence: a.szczerba@uwm.edu.pl; Tel.: +48-604-591-361 \\ + These authors contributed equally to this work.
}

Received: 15 July 2020; Accepted: 16 September 2020; Published: 18 September 2020

Simple Summary: Salmonella enterica subsp. enterica derived from poultry meat is the primary cause of Salmonella infection in humans and the second most ubiquitous zoonosis in the European Union after campylobacteriosis. Wildlife animals and livestock can be a reservoir of Salmonella spp., and they can contribute to the persistence of bacteria in the environment. Salmonella spp. pathogens can also be a source of widespread infections in fur-bearing animals, such as foxes (Vulpes vulpes) and mink (Neovison vision). This study analysed the prevalence of Salmonella spp. in two Arctic fox (Alopex lagopus) farms and the correlations between animals that tested positive for Salmonella spp and breeding results. Salmonella Heidelberg, S. Saintpaul, and S. Reading were isolated. All three serotypes are typically isolated from commercial poultry flocks. In this study, Salmonella spp. increased the risk of female infertility, but further research is needed to confirm the results. This is the first report on the prevalence of S. Heidelberg, S. Saintpaul, and S. Reading in an Arctic fox (Alopex lagopus) population.

\begin{abstract}
The objective of the study was to determine the occurrence of Salmonella spp. infections in two Arctic fox (Alopex lagopus) farms in Poland, and to analyse the correlations between animals that tested positive for Salmonella spp and breeding results. Faecal samples were taken from 1094 clinically healthy blue foxes from the basic stock of farms A and B. Salmonella spp. were detected in $18.06 \%$ (56/310) of the samples collected in farm A and in 15.94\% (125/784) of the samples collected in farm B. All isolated strains belonged to S. enterica subsp. enterica serotypes Salmonella Saintpaul (S. Saintpaul), Salmonella Reading (S. Reading), and Salmonella Heidelberg (S. Heidelberg). All three serotypes are typically isolated from commercial poultry flocks. Salmonella spp. infections significantly increased the risk of female infertility, but further research is needed to confirm the results. This is the first report on the prevalence of $S$. Heidelberg, S. Saintpaul, and S. Reading in faecal samples collected from Arctic fox (Alopex lagopus) farms in Poland.
\end{abstract}

Keywords: Salmonella spp.; epidemiology; one health approach; arctic foxes; Poland

\section{Introduction}

Salmonella enterica subsp. enterica derived from poultry meat is the primary cause of Salmonella infection in humans worldwide [1]. In 2018, 91,857 confirmed cases of Salmonella species (spp.) infections were registered in the European Union (EU), making salmonellosis the second most frequently reported zoonosis in the EU after campylobacteriosis $(N=246,571)$ [2]. More than 2500 serotypes have been identified to date, but most human infections are caused by only several serotypes [3]. In humans, Salmonella spp. pathogens are transmitted through food of animal origin, such as eggs, chicken, pork, or beef [4]. Salmonella spp. can be transmitted between animal species and between animals and humans, including by vectors [5-7]. Salmonella spp. are excreted with the faeces of healthy animals 
for long periods of time and can be isolated at any stage of the food chain [8,9]. Salmonella spp. are also one of the most common sources of infectious outbreaks in fur-bearing animals such as mink (Neovison vision) and foxes (Vulpes vulpes) [10]. The data on the epidemiological distribution of Salmonella spp. in mink and foxes are very limited. Salmonella spp. pathogens are transmitted when farmed animals are fed the meat of infected animals [11]. Feed of animal origin should constitute the bulk of fox diets (70-85\%). The quality and composition of feed are not always strictly monitored. Feeds of low quality can introduce undesirable ingredients into the food chain. Fox feeds are composed mainly of fish, fish offal, poultry, poultry offal, abattoir offal, and cereals with mineral and vitamin supplements. These feeds are the main sources of infection in carnivorous fur-bearing animals [11,12]. Salmonella spp. infections lead to disorders of the digestive system, including abdominal and intestinal problems. Typical symptoms include diarrhoea, vomiting, and fever, but Salmonella spp. can also cause miscarriage and foetal death [10]. A high mortality rate was reported in infected newborns in the first days of life.

The objective of this study was to determine the occurrence of Salmonella spp. infections in two Arctic fox (Alopex lagopus) farms in Poland and to analyse the correlations between animals that tested positive for Salmonella spp. and breeding results.

\section{Materials and Methods}

\subsection{Sample Collection}

The study was performed on 1094 fresh faecal samples obtained from the basic stock of clinically healthy and variously aged male and female Arctic foxes (Alopex lagopus). The animals were bred in two farms (A and B) in the Polish region of Warmia and Mazury. The farms were selected by a veterinarian specialising in diseases of fur-bearing animals for convenience sampling. Arctic foxes were housed in individual cages according to the provisions of the Regulation of the Minister of Agriculture and Rural Development of 28 June 2010 [13]. All adult animals were tested only once. Between October 2014 and May 2015, a total of 310 of fresh faecal samples were collected underneath the cages occupied by 250 females and 60 males in farm A, and a total of 784 fresh faecal samples were collected underneath the cages occupied by 624 females and 160 males in farm B. Faecal samples were placed in sterile plastic tubes and transported in a refrigerator to the laboratory within $8 \mathrm{~h}$.

\subsection{Bacteriological Examination}

Faecal samples of approximately $25 \mathrm{~g}$ each were initially incubated in $225 \mathrm{~mL}$ of Buffered Peptone Water (BPW) for $20-24 \mathrm{~h}$ at $37^{\circ} \mathrm{C}$ under aseptic conditions. Salmonella spp. were isolated according to Polish Standards [14]. Five typical colonies were selected from each culture for further identification. Bacterial species were confirmed using the API20E biochemical test kit (bioMerieux, Marcy l'Etoile, France). All strains were stored at $-80{ }^{\circ} \mathrm{C}$ in Brain Heart Infusion broth (Difco, BD, Franklin Lakes, NJ, USA) supplemented with $15 \%$ glycerine (Merck KGaA, Darmstadt, Germany).

\subsection{Serotyping}

Serotyping was performed by agglutination using commercial sera for $\mathrm{O}$ and $\mathrm{H}$ antigens (Difco, $\mathrm{BD}$, Sparks, MD), according to Kauffmann-White classification [3].

\subsection{Epidemiological and Statistical Analyses}

The Clopper-Pearson 'exact' method based on the beta distribution at a significance level of $\alpha=0.05$ and $95 \%$ confidence interval was applied in basic statistical analyses. Data were processed statistically with EpiTools open-source epidemiological calculators [15]. The correlations between the number of females that had given birth/ females that had miscarried/ infertile females vs. the number of live-born/weaned cubs of Salmonella-positive and negative females were determined in Fisher's exact test. Relative risk and attributable risk were calculated in cohort observational studies 
at a significance level of $\alpha=0.05$ and $95 \%$ confidence interval using the Working in Epidemiology (WinEpi) open-source programme. The reproduction rate and the case fatality rate (CFR) in cubs were calculated based on the adopted breeding indices for fur-bearing animals.

\section{Results}

In farm $\mathrm{A}, 14.4 \%$ of the analysed females $(36 / 250,95 \% \mathrm{CI}=10.29-19.37)$ and $33.33 \%$ of the males $(20 / 60,95 \%$ CI $=21.69-46.69)$ tested positive for Salmonella spp. All strains belonged to Salmonella enterica subsp. enterica serotype Heidelberg (S. Heidelberg) $(n=56)$. In the group of Salmonella-positive females, $55.56 \%$ had given birth $(20 / 36,95 \% \mathrm{CI}=38.10-72.06), 16.67 \%$ had miscarried $(6 / 36,95 \% \mathrm{CI}=6.37-32.81)$, and $27.78 \%$ were infertile $(10 / 36,95 \% \mathrm{CI}=14.20-45.19)$. In the group of Salmonella-negative females, $70.56 \%$ had given birth $(151 / 214,95 \% \mathrm{CI}=63.96-76.58), 14.49 \%$ had miscarried $(31 / 21495 \% \mathrm{CI}=10.06-19.93)$, and $14.95 \%$ were infertile $(32 / 214,95 \% \mathrm{CI}=10.46-20.45)$. The results of bacteriological and serological analyses are shown in Table 1.

In farm B, $16.99 \%$ of the evaluated females $(106 / 624,95 \% \mathrm{CI}=14.12-20.12)$ and $11.88 \%$ of the males $(19 / 160,95 \%$ CI $=7.30-17.92)$ tested positive for Salmonella spp. Salmonella enterica subsp. enterica serotype Saintpaul (S. Saintpaul) was identified in $66.04 \%$ of the females $(70 / 106,95 \%$ CI $=56.20-74.96)$ and $68.42 \%$ of the males $(13 / 19,95 \% \mathrm{CI}=43.45-87.42)$. Salmonella enterica subsp. enterica serotype Reading (S. Reading) was identified in $33.96 \%$ of the females $(36 / 106,95 \% \mathrm{CI}=25.04-43.80)$ and $31.58 \%$ of the males $(6 / 19,95 \% \mathrm{CI}=12.58-56.55)$. The results are shown in Table 1 . In the group of Salmonella-positive females, $82.08 \%$ had given birth $(87 / 106,95 \% \mathrm{CI}=73.43-88.85), 10.38 \%$ had miscarried $(11 / 106,95 \% \mathrm{CI}=5.30-17.81)$, and $7.55 \%$ were infertile $(8 / 106,95 \% \mathrm{CI}=3.31-14.33)$. In the group of Salmonella-negative females, $86.68 \%$ had given birth $(449 / 518,95 \% \mathrm{CI}=83.45-89.49), 10.23 \%$ had miscarried $(53 / 518,95 \% \mathrm{CI}=7.76-13.17)$, and $3.09 \%$ were infertile $(16 / 518,95 \% \mathrm{CI}=1.78-4.97)$. The correlations between the number of Salmonella-positive and negative females that had given birth/had miscarried/were infertile were not significant ( $p$-values in the two-tailed test: $0.08,0.79,0.08$ in farm $\mathrm{A}$, and $0.22,1.00,0.04$ in farm B, respectively).

The calculated risk estimates for Salmonella-positive females that had given birth/had miscarried/were infertile differed between farms. No significant differences were observed among Salmonella-positive females that had given birth/had miscarried, but in the group of infertile females, the relative risk was determined at $1.85(95 \% \mathrm{CI}=1.00-3.43)$ in farm $\mathrm{A}$ and $2.44(95 \% \mathrm{CI}=1.07-5.56)$ in farm B, respectively. The risk of infertility in Salmonella-positive females was determined at $12.82 \%$ in farm A and $4.46 \%$ in farm B, respectively.

The number of live-born/weaned cubs delivered by Salmonella-positive and negative females was determined at 3.20/3.15 and 5.23/4.85 per mother in farm $\mathrm{A}$, and at 9.38/7.06 and 9.57/7.03 per mother in farm B, respectively. The results are collated in Table 1 . The case fatality rate (CFR) among the offspring of Salmonella-positive and negative females was determined at $1.59 \%$ and $7.34 \%$ in farm A, and at $24.63 \%$ and $26.49 \%$ in farm B, respectively. The correlations between the number of live-born/weaned cubs delivered by Salmonella-positive and negative females were not statistically significant. Cub mortality was $23.07 \%$ higher in farm B than in farm A. 
Table 1. Prevalence of Salmonella spp. and reproductive success in Arctic foxes (Alopex lagopus).

\begin{tabular}{|c|c|c|c|c|c|c|c|c|}
\hline \multirow[t]{2}{*}{$\begin{array}{c}\text { Reproductive Success } \\
\text { Total }\end{array}$} & \multicolumn{2}{|c|}{$\begin{array}{c}\text { Farm A } \\
\text { Females } \\
\quad 250\end{array}$} & \multicolumn{2}{|c|}{$\begin{array}{c}\text { Farm A } \\
\text { Males } \\
60\end{array}$} & \multicolumn{2}{|c|}{$\begin{array}{c}\text { Farm B } \\
\text { Females } \\
\quad 624\end{array}$} & \multicolumn{2}{|c|}{$\begin{array}{c}\text { Farm B } \\
\text { Males } \\
160\end{array}$} \\
\hline & $\begin{array}{l}\text { Salmonella- } \\
\text { Negative }\end{array}$ & $\begin{array}{l}\text { Salmonella- } \\
\text { Positive }\end{array}$ & $\begin{array}{l}\text { Salmonella- } \\
\text { Negative }\end{array}$ & $\begin{array}{l}\text { Salmonella- } \\
\text { Positive }\end{array}$ & $\begin{array}{l}\text { Salmonella- } \\
\text { Negative }\end{array}$ & $\begin{array}{l}\text { Salmonella- } \\
\text { Positive }\end{array}$ & $\begin{array}{l}\text { Salmonella- } \\
\text { Negative }\end{array}$ & $\begin{array}{l}\text { Salmonella- } \\
\text { Positive }\end{array}$ \\
\hline Total & 214 & 36 & 40 & 20 & 518 & 106 & 141 & 19 \\
\hline $\begin{array}{l}\text { No. offemalesthat gave } \\
\text { birth }\end{array}$ & 151 & 20 & - & - & 449 & 87 & - & - \\
\hline $\begin{array}{l}\text { No. of females that } \\
\text { miscarried }\end{array}$ & 31 & 6 & - & - & 53 & 11 & - & - \\
\hline No. of infertile females & 32 & 10 & - & - & 16 & 8 & - & - \\
\hline $\begin{array}{l}\text { No. of live-born cubs/No. of } \\
\text { females that } \\
\text { gave birth }\end{array}$ & $790 / 151=5.23$ & $64 / 20=3.2$ & - & - & $\begin{array}{c}4299 / 449= \\
9.57\end{array}$ & $816 / 87=9.38$ & - & - \\
\hline $\begin{array}{c}\text { No. of weaned puppies/No. } \\
\text { of females } \\
\text { that gave birth }\end{array}$ & $732 / 151=4.85$ & $63 / 20=3.15$ & - & - & $\begin{array}{c}3160 / 449= \\
7.03\end{array}$ & $615 / 87=7.06$ & - & - \\
\hline Case fatality rate (CFR) & 7.34 & 1.56 & - & - & 26.49 & 24.63 & & \\
\hline \multicolumn{9}{|l|}{$\begin{array}{c}\text { S. enterica subsp. enterica } \\
\text { serotype }\end{array}$} \\
\hline Saintpaul & & & & & & 70 & & 13 \\
\hline Reading & & & & & & 36 & & 6 \\
\hline Heidelberg & & 36 & & 20 & & & & \\
\hline
\end{tabular}




\section{Discussion}

The One Health approach was developed in the early 2000s with the goal of recognising the continuous, cumulative and globally interdependent interactions between causes and effects within ecosystems and their human and animal populations. This approach can be applied to food security, economic sustainability, and animal welfare [16,17]. Free-living red foxes (Vulpes vulpes) can be a reservoir of Salmonella spp. In an Italian study, Salmonella spp. were identified in 5.7\% of the tested samples, in Austria at 2.1\%, and in Norway at 6.5\%, respectively [18-20]. In Poland, the prevalence of Salmonella spp. in free-living foxes (Vulpes vulpes) was determined at 3.15\% [21]. The prevalence of Salmonella spp. in farmed foxes reached 4.2\% [22]. These studies indicate that free-living red foxes (Vulpes vulpes) harbour numerous Salmonella spp. serotypes which are also responsible for infections in Europe [23]. In the present study, the prevalence of Salmonella spp. in Arctic foxes (Alopex lagopus) was determined at $18.06 \%$ (56/310) in farm A, and 15.94\% (125/784) in farm B. All isolated serotypes (S. Saintpaul, S. Reading, and S. Heidelberg) belonged to S. enterica subsp. enterica. The identified serotypes are commonly encountered in commercial poultry farms which are the primary reservoirs of all Salmonella spp. serotypes in different countries $[24,25]$ and may trigger human infections around the world [25-27]. The presence of these poultry pathogens in foxes results from feeding these animals with poultry slaughter waste, mainly from turkey processing. In 1999 and 2009, S. Saintpaul, S. Senftenberg, S. Anatum, S. Heidelberg, S. Hadar, S. Typhimurium, S. Infantis, S. Enteritidis, and S. Agona were isolated from chicken and turkey carcasses in north-eastern Poland [12,28]. In 2014 and 2016, S. Enteritidis, S. Typhimurium, S. Anatum, S. Kentucky, S. Infantis, and S. Mbandaka were isolated from broiler chicken flocks in the same region [29]. Warmia and Mazury is a leading producer of turkeys in Poland, and it is characterised by high availability of poultry slaughter waste, including hard waste such as heads and legs, or soft waste such as meat and bone meal. These nutritious and energy-dense feed components are often acquired and stored in poor sanitary conditions, which can lead to the contamination of entire feed lots, mainly with Salmonella rods. Hygiene standards in hatcheries and poultry processing plants have to be improved to prevent the circulation of Salmonella spp. serotypes in poultry feed, animals, and the environment [30].

Correlations between animals that tested positive for Salmonella spp and the breeding results of Arctic foxes (Alopex lagopus) were also determined in the study. The only statistically significant result was that in both farms, Salmonella-positive females were at higher risk of infertility. Reproductive problems have a complex aetiology in Arctic foxes, and numerous factors that affect fertility need to be controlled, including in statistical analyses. In the examined farms, CFR values were not correlated with the number of Salmonella-positive or negative females. The risk of cub mortality was around $23.07 \%$ higher in the larger farm (B), but further research is needed to confirm these results.

\section{Conclusions}

In the present study, the prevalence of Salmonella spp. in Arctic foxes (Alopex lagopus) in the examined farms was estimated between $15.94 \%$ and $18.06 \%$. All isolated strains were identified as serotypes S. Saintpaul, S. Reading, and S. Heidelberg of S. enterica subsp. enterica which are potentially pathogenic for humans. The risk of infertility was significantly higher in the population of Salmonella-positive females at 4.46-12.82\%. This is the first report on the prevalence of S. Heidelberg, S. Saintpaul, and S. Reading in faecal samples collected from Arctic fox (Alopex lagopus) farms in Poland.

Author Contributions: Conceptualization, J.S. and K.P.; methodology, J.S.; K.P., and A.S.-T.; software, A.S.-T.; validation, J.S., K.P., and A.S.-T.; formal analysis, J.S. and A.S.-T.; writing-original draft preparation, J.S. and A.S.-T.; writing-review and editing, J.S.; K.P., and A.S.-T.; supervision, J.S. All authors have read and agreed to the published version of the manuscript.

Funding: Project financially supported by Minister of Science and Higher Education in the range of the program entitled "Regional Initiative of Excellence" for the years 2019-2022, Project No. 010/RID/2018/19, amount of funding 12.000.000 PLN".

Acknowledgments: The authors would like to thank fox farm owners for facilitating this study. 
Conflicts of Interest: The authors declare no conflict of interest.

\section{References}

1. Foley, S.L.; Johnson, T.J.; Ricke, S.C.; Nayak, R.; Danzeisen, J. Salmonella pathogenicity and host adaptation in chicken-associated serovars. Microbial. Mol. Biol. Rev. 2013, 77, 582-607. [CrossRef] [PubMed]

2. EFSA and ECDC (European Food Safety Authority and European Centre for Disease Prevention and Control). The European Union One Health 2018 Zoonoses Report. EFSA J. 2019, 17. [CrossRef]

3. Grimont, P.A.D.; Weill, F.X. Antigenic Formulae of the Salmonella Serovars, 9th ed.; WHO Collaborating Center for Reference and Research on Salmonella, Institut Pasteur: Paris, France, 2007.

4. Pires, S.M.; Vigre, H.; Makela, P.; Hald, T. Using outbreak data for source attribution of human salmonellosis and campylobacteriosis in Europe. Foodborne Pathog. Dis. 2010, 7, 1351-1361. [CrossRef] [PubMed]

5. Rubini, S.; Ravaioli, C.; Previato, S.; D’Incau, M.; Tassinari, M.; Guidi, E.; Lupi, S.; Merialdi, G.; Bergamini, M. Prevalence of Salmonella strains in wild animals from a highly populated area of north-eastern Italy. Ann. Ist. Super. Sanita. 2016, 52, 277-280. [PubMed]

6. Wales, A.D.; Carrique-Mas, J.J.; Rankin, M.; Bell, B.; Thind, B.B.; Davies, R.H. Review of the carriage of zoonotic bacteria by arthropods, with special reference to Salmonella in mites, flies and litter beetles. Zoonoses Public Health 2010, 57, 299-314.

7. Krawiec, M.; Kuczkowski, M.; Kruszewicz, A.G.; Wieliczko, A. Prevalence and genetic characteristics of Salmonella in free-living birds in Poland. BMC Vet. Res. 2015, 11, 15. [CrossRef]

8. Paulsen, P.; Smulders, F.J.M.; Hilbert, F. Salmonella in meat from hunted game: A central Europe perspective. Food Res. Int. 2012, 45, 609-616. [CrossRef]

9. Hilbert, F.; Smulders, F.J.M.; Chopra-Dewasthaly, R.; Paulsen, P. Salmonella in the wildlife-human interface. Food Res. Int. 2012, 45, 603-608. [CrossRef]

10. Dietz, H.H.; Chriél, M.; Andersen, T.H.; Jørgensen, J.C.; Torpdahl, M.; Pedersen, H.; Pedersen, K. Outbreak of Salmonella Dublin-associated abortion in Danish fur farms. Can. Vet. J. 2006, 47, 1201-1205.

11. European Commission Health \& Consumer Protection Directorate-General. The Welfare of Animals Kept for Fur Production. Report of the Scientific Committee on Animal Health and Animal Welfare. Scientific Steering Committee at Its Meeting of 12-13 December 2001. Available online: https:/ec.europa.eu/food/sites/ food/files/safety/docs/sci-com_scah_out67_en.pdf (accessed on 12 April 2020).

12. Mikołajczyk, A.; Radkowski, M. Salmonella spp. on chicken cracasses in a processing plant in Poland. J. Food Prot. 2002, 65, 1475-1479. [CrossRef]

13. Regulation of the Minister of Agriculture and Rural Development of 28 June 2010 on the Minimum Requirements for Breeding Animal Species other than the Species for which the Applicable Protection Standards have been Laid down by European Union Regulations. Polish Journal of Laws No. 116 (2010), Item 778. Available online: http://isap.sejm.gov.pl/isap.nsf/download.xsp/WDU20101160778/O/D20100778. pdf (accessed on 10 August 2020). (In Polish)

14. Polish Committee for Standardization. Microbiology of Food and Animal Feeding Stuffs—Horizontal Method for the Detection of Salmonella spp.; PN-EN ISO 6579:2003; Polish Committee for Standardization: Warsaw, Poland, 2003.

15. Sergeant, E.S.G. Epitools Epidemiological Calculators. Ausvet. 2018. Available online: http://epitools.ausvet. com.au (accessed on 10 May 2020).

16. Evans, B.R.; Leighton, F.A. A history of One Health. Rev. Sci. Tech. Off. Int. Epiz. 2014, 33, 413-420. [CrossRef] [PubMed]

17. Ruegg, S.R.; McMahon, B.J.; Hasler, B.; Esposito, R.; Nielsen, L.R.; Speranza, C.I.; Ehlinger, T.; Peyre, M.; Aragrande, M.; Zinsstag, J.; et al. A Blueprint to evaluate One Health. Front. Public Health 2017, 5. [CrossRef] [PubMed]

18. Chiari, M.; Ferrari, N.; Giardiello, D.; Lanfranchi, P.; Zanoni, M.; Lavazza, A.; Alborali, L.G. Isolation and identification of Salmonella spp. from red foxes (Vulpes vulpes) and badgers (Meles meles) in northern Italy. Acta Vet. Scand. 2014, 56, 86. [CrossRef] [PubMed]

19. Glawischnig, W.; Lazar, J.; Wallner, A.; Kornschober, C. Cattle-derived Salmonella enterica serovar Dublin infections in Red Foxes (Vulpes vulpes) in Tyrol, Austria. J. Wildl. Dis. 2017, 53, 361-363. [CrossRef] 
20. Handeland, K.; Nesse, L.L.; Lillehaug, A.; Vikøren, T.; Djønne, B.; Bergsjø, B. Natural and experimental Salmonella Typhimurium infections in foxes (Vulpes vulpes). Vet. Microbiol. 2008, 132, 129-134. [CrossRef]

21. Nowakiewicz, A.; Zięba, P.; Ziółkowska, G.; Gnat, S.; Muszyńska, M.; Tomczuk, K.; Majer Dziedzic, B.; Ulbrych, Ł.; Trościańczyk, A. Free-Living Species of Carnivorous Mammals in Poland: Red Fox, Beech Marten, and Raccoon as a Potential Reservoir of Salmonella, Yersinia, Listeria spp. and Coagulase-Positive Staphylococcus. PLoS ONE 2016, 12, e0155533. [CrossRef]

22. Kłapeć, T.; Cholewa, A.; Kostro, K.; Karamon, J.; Zdybel, J. Występowanie pasożytów jelitowych i salmonelli w odchodach lisów i norek hodowlanych w fermach województwa lubelskiego w aspekcie ich rolniczego wykorzystania. Prevalence of intestinal parasites and Salmonella in the feaces of farm-bred foxes and mink in Lublin Voivodeship as a potential risk in agriculture use. Med. Weter. 2015, 71, 787-790.

23. Hendriksen, R.S.; Vieira, A.R.; Karlsmose, S.; Lo Fo Wong, D.M.; Jensen, A.B.; Wegener, H.C.; Aarestrup, F.M. Global monitoring of Salmonella serovar distribution from the World Health Organization Global Foodborne Infections Network Country Data Bank: Results of quality assured laboratories from 2001 to 2007. Foodborne Pathog. Dis. 2011, 8, 887-900. [CrossRef]

24. Foley, S.L.; Lynne, A.M.; Nayak, R. Salmonella challenges: Prevalence in swine and poultry and potential pathogenicity of such isolates. J. Anim. Sci. 2008, 86, E149-E162. [CrossRef]

25. Miller, E.A.; Elnekave, E.; Flores-Figueroa, C.; Johnson, A.; Kearney, A.; Munoz-Aguayo, J.; Tagg, K.A.; Tschetter, L.; Weber, B.P.; Nadon, C.A.; et al. Emergence of a novel Salmonella enterica serotype Reading clonal group is linked to its expansion in commercial turkey production, resulting in unanticipated human illness in North America. mSphere 2020, 5, e00056-20. [CrossRef]

26. Thomson, R.M.; Henderson, H.J.; Smith-Palmer, A. An outbreak of Salmonella Saintpaul in a Scottish childcare facility: The influence of parental under-reporting. BMC Infect. Dis. 2019, 19, 847. [CrossRef] [PubMed]

27. Etter, A.J.; West, A.M.; Burnett, J.L.; Wu, S.T.; Veenhuizen, D.R.; Ogas, R.A.; Oliver, H.F. Salmonella enterica subsp. enterica serovar Heidelberg food isolates associated with a Salmonellosis outbreak have enhanced stress tolerance capabilities. Appl. Environ. Microbiol. 2019, 85, e01065-19. [CrossRef] [PubMed]

28. Zdrodowska, B.; Liedtke, K.; Radkowski, M. Post-harvest Salmonella spp. prevalence in turkey carcasses in processing plant in the northeast part of Poland. Pol. J. Vet. Sci. 2014, 17, 181-183. [CrossRef] [PubMed]

29. Witkowska, D.; Kuncewicz, M.; Żebrowska, J.P.; Sobczak, J.; Sowińska, J. Prevalence of Salmonella spp. in broiler chicken flocks in northern Poland in 2014-2016. Ann. Agric. Environ. Med. 2018, 25, 693-697. [CrossRef]

30. Sławoń, J.; Saba, L.; Bis-Wencel, H.; Wencel, C. Pałeczki Salmonella w środowisku ferm mięsożernych zwierzat futerkowych. Salmonella spp. occurrence on farms of fur-bearing carnivourous animals. Med. Weterynaryjna 1994, 5, 545-548.

(C) 2020 by the authors. Licensee MDPI, Basel, Switzerland. This article is an open access article distributed under the terms and conditions of the Creative Commons Attribution (CC BY) license (http://creativecommons.org/licenses/by/4.0/). 